ppi $201502 Z U 4645$

Esta publicación científica en formato digital es continuidad de la revista impresa ISSN-Versión Impresa 0798-1406 / ISSN-Versión on line 2542-3185Depósito legal pp $197402 Z$ U34

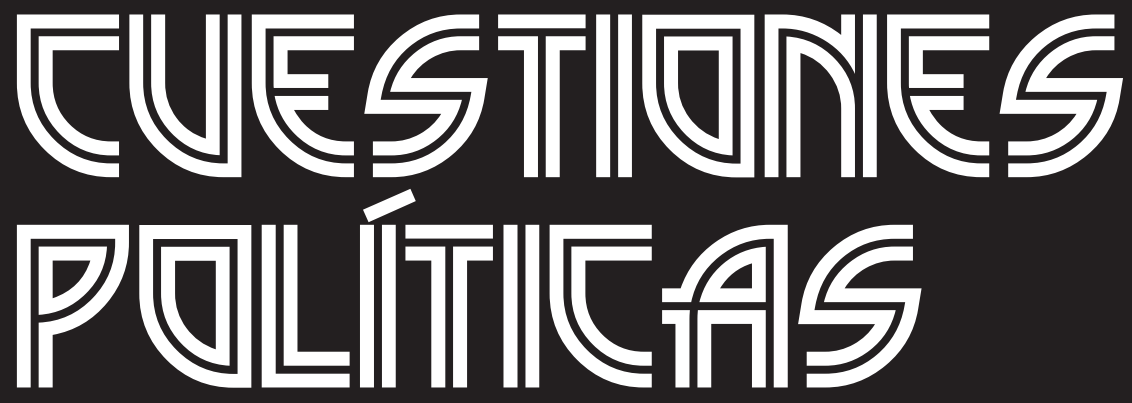

Instituto de Estudios Políticos y Derecho Público "Dr. Humberto J. La Roche" de la Facultad de Ciencias Jurídicas y Políticas de la Universidad del Zulia Maracaibo, Venezuela
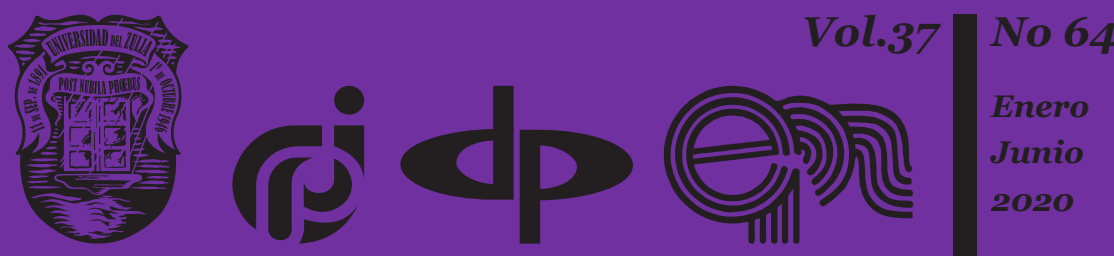


\title{
Policies of pedagogical maintenance of students ready for a safe life in inclusive education
}

\author{
Busygina Tatyana Alexandrovna * \\ Aleksandr A. Korostelev ** \\ Elena I. Artemova *** \\ Larisa Aleksandrovna Kolyvanova **** \\ Tamara Mikhailovna Nosova ${ }^{* * * * *}$ \\ Ivan Ivanovich Pavlov ****** \\ Svetlana Mikhailovna Thomas *******
}

\begin{abstract}
The article aimed to review some pedagogical policies for the inclusion and a safe life of people with disabilities. Training the preparation of people with disabilities and disabilities for a safe life is more effective within the framework of an accessible and organized educational environment in the educational institution, which guarantees the solution of professional problems in the training of future middle-level specialists. For a safe stay in society. Under the provision of people with health problems for a safe life, we consider the complex subjective property of a person with a disability, which manifests itself when it understands the dangers that have arisen in the educational environment and in various areas of life and we provide a way to overcome them. It is concluded that without an accessible and wellorganized educational environment, it is impossible to achieve the result of establishing harmonious relationships between people with disabilities and the social environment that determine their greater disposition for a safe entry into society and a full life in modern society. Particular attention is paid in the process of vocational training for people with disabilities to
\end{abstract} individualization.

Keywords: inclusion policies in pedagogy; inclusive education; life safety;

People with disabilities; Person with Disability.

\footnotetext{
* Samara State Socio-Pedagogical University, Russia. Email: azshar2017@mail.ru.

** Togliatti State University, Russia. Email: korostelev_@mail.ru.

*** Kuban State Agrarian University Named after I.T. Trubilin, Russia. Email: artemova@yandex.ru.

****S Samara State Socio-Pedagogical University, Russia. Email: kolyanova@mail.ru.

***** Samara State Socio-Pedagogical University, Russia. Email: nosova@rambler.ru.

******Ｎorth-Eastern Federal University, Russia. Email: pavlov_@rambler.ru.

*******Utrecht University, The Netherlands. Email: thomas@mail.ru.
}

Recibido: 12/08/2019.

Aceptado: 31/03/20. 


\title{
Políticas de mantenimiento pedagógico de estudiantes listos para una vida segura en la educación inclusiva
}

\begin{abstract}
Resumen
El artículo tuvo por objetivo revisar algunas políticas padagógicas para la inclusión y una vida segura de personas con discapacidad. La formación de la preparación de las personas con discapacidad y discapacidades para una vida segura es más efectiva en el marco de un entorno educativo accesible y organizado en la institución educativa, que garantiza la solución de problemas profesionales en la formación de futuros especialistas de nivel medio. Para una estancia segura en la sociedad. Bajo la disposición de las personas con problemas de salud para una vida segura, consideramos la propiedad subjetiva compleja de una persona con discapacidad, que se manifiesta cuando comprende los peligros que han surgido en el entorno educativo y en diversas áreas de la vida y le brindamos una manera de superarlos. Se concluye que sin un entorno educativo accesible y bien organizado, es imposible lograr el resultado de establecer relaciones armoniosas entre las personas con discapacidad y el entorno social que determinen su mayor disposición para una entrada segura en la sociedad y una vida plena en la sociedad moderna. Se presta especial atención en el proceso de formación profesional para personas con discapacidad a la individualización.
\end{abstract}

Palabras clave: políticas de inclusión en pedagogía; educación inclusiva; seguridad de vida; personas con discapacidad; persona con discapacidad.

\section{Introduction}

In the modern world, the problem of ensuring life safety in its various fields is of particular relevance. Many researchers (Rybalkin, 2006; Yakupov, 2008; Kuznetsov, 2009; Beck,2000; Baklunova, 2017; Shuvalova, 2018) OV and others highlight the safety of society, which implies the safety of the individual, certain groups of the population and the state as a whole Of particular importance is the safety of life for people with disabilities and disabilities, however, it is worth noting that more attention is currently being paid to building an architectural accessible (safe) environment than creating the necessary conditions for ensuring the safety of persons with impairments in all aspects of their life, including in vocational education. 
Busygina T. Alexandrovna, Aleksandr A. Korostelev, Elena I. Artemova, Larisa A. Kolyvanova, Tamara M. Nosova, Ivan I. Pavlov y Svetlana M. Thomas

Asyou know, the effectiveness of pedagogical supportfor the preparedness of persons with disabilities for safe life in the process of obtaining special vocational education will be determined by the desire and ability of the educational organization to create the psychological, pedagogical and socio-organizational conditions necessary for its achievement.

The analysis of the experience of professional organizations providing inclusive education shows that far from everywhere there is an idea that the safe life of persons with disabilities is based on their understanding of the dangers in the environment that become an integral part of their future work. As a rule, the teaching staff of these educational organizations, trying to create the readiness of such students for safe life, does not fully pay attention to the types of dangers that actually exist in their life and professional sphere, do not focus on their prevention and avoidance, and do not develop the ability to evaluate their own forces and opportunities to overcome them.

\section{Methodology}

Today, the issue of pedagogical support for preparedness for safe life of persons with disabilities is a relatively new scientific problem in modern education. However, as the analysis of scientific literature shows, in the vocational education system there are theoretical prerequisites for its study. First of all, V.P. Belyaeva A.V. Vereshchagina, S.A. Vorontsova and A.V. Ponedelkova, in which the content of certain types of security (national, state, social, etc.) is raised (Belyaev et al, 2016; Ponedelkov \& Vorontsov, 2015). The scientific works of S.P. are devoted to the development of the theory of life safety and the identification of the possibilities for its implementation in the educational process. (Danchenko, 2016), S.V. Abramova, P.V. Stankevich, E.N. Boyarova, M.U. (Elipkhanov \& Okazova, 2018; Tsvetkova, 2018) (Kamerilova et al, 2017), G.A. Kostenko, V.P., (Solomin \& Stankevich, 2014). In addition, various aspects (social-group, interpersonal, intrapersonal, etc.) of the psychological safety of subjects of education are presented in the works of I.A. Bayeva, L.I. Shakhovoy, D.Kh. Guryeva, V.M (Miniyarov \& Orlova, 2016) (Mekhant'yeva et al, 2016).

As you know, the concept of «security» has multiple interpretations, one of which is the definition of V.P. Belyaeva (Belyaev et al, 2016), which characterizes him primarily as a certain dynamic state, for the maintenance of which purposeful activity is carried out. The author in his study notes that after the end of the Cold War in Russia, simultaneously with socio-political discussions, an official state security concept was developed, which was subsequently expressed in the adoption of official documents that outlined the main issues of its safe development strategy. 
Indeed, the first attempt to define security was made in Art. 1 of the Law of the Russian Federation "On Security", enforced by the Resolution of the Supreme Council on March 5, 1992, where it was defined as "a state of protection of the vital interests of the individual, society and the state as a whole from internal and external threats". Later, the concept of "security" was reflected in the Message of the President of Russia to the Federal Assembly of the Russian Federation (On National Security, 1996), and then in the Concept of National Security of the Russian Federation, approved by Decree of the President of the Russian Federation in December 1997 and amended in 2000 the year when it came to the independence of such concepts as "state security" and "national security", speaking of their nonidentity and the impossibility of uniting as a whole, since the first is the most important component of the second.

In his numerous studies, Doctor of Sociology, Professor of the Department of Sociology, Political Science and Law, Institute of Retraining and Further Training of Teachers of Humanities and Social Sciences of the Southern Federal University A.V. Vereshchagina (Samygin \& Vereshchagina, 2014) came to the conclusion that security is inextricably linked with the state of the social system, the level of its balance and the development of elements that ensure its further functioning. However, the author notes that in order to ensure the balance of the social system and its security, it is necessary to carry out social activities aimed at maintaining the existing balance of the system, its integrity and sustainability.

In the work of S.I. Samygina (Samygin \& Vereshchagina, 2014) considers one of the components of national security - social security, which is defined by the author as a way of functioning of a social system in the process of interaction of its structural subsystems (economic, political, demographic, informational, cultural, etc.) and elements (social groups, organizations, institutions, individuals) among themselves and with the environment in the process of society. According to the scientist, this definition of social security is based on an understanding of danger as a way of existence of a social system.

At the same time S.I. Samygin emphasizes that, within the framework of philosophical understanding, the security phenomenon implies a certain sequence in its study, associated with the desire to understand the essence of this phenomenon, as well as determine its target nature, implemented in an activity-based approach to the concept of «security».

Having analyzed the problems of ensuring the life safety of people with disabilities and disabilities from the point of view of considering them as a demographic unit, it is worth noting the scientific work in this area of the Honored Scientist of the Russian Federation, Professor of the South Russian Institute of Management - a branch of the Russian Presidential Academy of National Economy and Public Administration under the President of the 
Busygina T. Alexandrovna, Aleksandr A. Korostelev, Elena I. Artemova, Larisa A. Kolyvanova, Tamara M. Nosova, Ivan I. Pavlov y Svetlana M. Thomas

Russian Federation A.V. Ponedelkova (Ponedelkov \& Vorontsov, 2015). The author's scientific study, in which he denotes the demographic situation of one of the important components of national security, is particularly interesting, since it is precisely because of the unresolved demographic problems that the political and socio-economic issues that arise in modern society and lead to the risk of danger arise. At the same time, his colleague, Doctor of Law, Professor S.A. Vorontsov (Ponedelkov \& Vorontsov, 2015) focuses on the fact that an important role in ensuring the security of the individual, society and the state as a whole belongs to the demographic situation, since the main asset and the only source of power in the country are its citizens, without whom it would simply be part of nature.

Thus, the effective and stable development of the state largely depends on the demographic characteristics of the population living in it. In this regard, one of the important tasks of ensuring the safety of citizens of the country is the determination of patterns and in-depth knowledge of the positive and negative trends that occur in their life, especially in the psychological and educational fields.

Important scientific works in the field of life safety of persons with special educational needs are scientific articles I.A. Baeva and L.I. Shakhova (Baeva \& Shakhova, 2016), in which researchers consider the main issues to ensure the psychological safety of all subjects of the educational process, its structure and anxiety as its leading element. In addition, the authors reveal the possibilities of assessing the psychological safety of the educational environment, determine its components (satisfaction, security, referentiality, subjective well-being of students in the educational environment, activity) and criteria.

Of course, it is difficult to disagree with the authors' assertion that security is a basic human need. Conducted by I.A. Baeva and L.I. (Shakhova, 2015: Baeva \& Shakhova, 2016), scientific studies have shown that increasing the level of psychological safety in the educational environment helps harmonize the psychological health of its subjects, and psychological safety itself is an indispensable criterion for assessing the quality of education.

In this sense, it is advisable to note the scientific research of D.Kh. Gurieva, which deals with the essence of the psychological security of the educational environment, which she considers both in a broad understanding of the conceptual approach to national security and in a narrow understanding of this category in the framework of professional activities of people in the «man - man» system.

According to the scientist, the creation of a safe social environment is one of the most important conditions of the educational process, where all its participants are given the opportunity for further personal development. In this regard, the psychological safety of the educational environment is 
presented as the most important resource that contributes to effective protection from the adverse effects of all subjects of the educational process, the main indicators of which are: the absence of psychological violence; friendly attitude to the educational environment and satisfaction with it.

Thus, considering the issues of ensuring the psychological safety of persons with disabilities in physical or mental development, the educational organization, as a social institution of the society, within the educational environment solves one of the most important tasks for their training and education, thereby contributing to the formation of a harmoniously developed personality, capable of self-development and safe behavior in the environment.

Based on this, under the formation of the concept of «educational environment» D.Kh. Gurieva implies the stage of registration and structuring of new student education programs based on the modern conditions of their safe stay in modern society. In numerous study, E.N. Boyarova (Boyarov, 2015) presents a deep theoretical analysis of the educational environment of a modern educational institution, defines a strategy for its further development aimed at creating the necessary conditions (organizational and pedagogical: breadth, intensity, generalization, coherence, activity and mobility of the educational environment; socio-organizational: creation of a modern educational material and technical base, social, medical and psychological support of the educational process, monitoring of educational process, safety diagnostics of the educational environment during training), contributing to the formation of a diverse, socially active, independent and competent person of the future specialist.

The essence of the educational environment, according to the authors, is the development of the personality of students who, through their actions and actions, activate the elements of this environment and, thereby, create it for themselves. Researchers note that the educational environment is generated by those components of the social environment (factors, conditions, resources, etc.) that are significantly interconnected with education, educational systems, and methodological systems.

\section{Results}

Speaking about the pedagogical system of ensuring students' readiness for a safe life and professional activity in the process of their training, P.V. Stankevich considers the sphere of education as a key link in the formation of a "safe" type of personality, focused on the effective development of society and aware of the value of its life and the need for health. Pointing 
Busygina T. Alexandrovna, Aleksandr A. Korostelev, Elena I. Artemova, Larisa A. Kolyvanova, Tamara M. Nosova, Ivan I. Pavlov y Svetlana M. Thomas

to the growth of psychological insecurity, hostility, intolerance and the unpreparedness of participants in the educational process to overcome dangerous life situations, the author focuses on studying not only the personal characteristics of individual students, but also on considering the characteristics of student groups, as well as the interaction of students and teachers as a component of educational security Wednesday. In addition, in the scientific work of P.V. Stankevich reveals the features of such interaction of all participants in the educational process, the effectiveness of which depends, first of all, on the chosen strategies of behavior of teachers and students in it, and on the level of tolerance of its participants - in the second.

Thus, the essence of the development of a safe educational environment according to P.V. Stankevich, is to create a psychologically safe educational environment in the educational process in the training of future specialists (Mitin et al, 2014). Based on the analysis of the problem identified by us, it follows that to ensure the preparedness of people with physical and mental health disorders for safe life, it is necessary not only to identify various kinds of obstacles (lack of means of social and environmental adaptation, discrimination, lack of communication with people around them, etc.) found in their lives, but also the creation of an accessible educational environment, which is one of the pedagogical conditions for ensuring the safe behavior of this category of citizens in a professional th field of activity. Our attention was drawn to the creation of a barrier-free educational environment for the training of persons with visual impairment that would satisfy their special needs.

This educational environment included accessible architectural space, material and technical base, content sphere (educational and training programs, curriculum, textbooks and teaching aids, etc.), communication sphere (communication and teaching style, spatial and social density among subjects of education, degree of crowding, etc.); as well as healthsaving technologies for vocational training of persons with developmental disabilities, which contributed to the development of their skills to lead a safe lifestyle and work.

After a detailed analysis of the scientific works of M.Y. (Chaikovskyi, 2014; Yakovleva, 2014) D.Z. (Akhmetova, 2014), V.P. Solomina, D.N. Uznadze, N.V. Liubavina, S.V. Guzenina, E.L. Iakovleva, A.M. Petrovsky, O. I. Vaganova, L.I. Kutepova, V.D. Shadrikova, we identified the main structural components (cognitive-semantic, communicative, active) of the readiness of people with health problems for safe life, thanks to which they were able to prevent and avoid danger, thereby ensuring a stable interaction with the environment Wednesday.

The effectiveness of our work was determined by comparing the results of the ascertaining stage of the experimental work with the data of its control stage, obtained using the same research methods. 
The changes that occurred in the cognitive-semantic component of the readiness of students with disabilities to safe life activities were determined using the conceptual dictionary method, monitoring their behavior and interaction with classmates and teachers, and their content was analyzed. It was revealed that students of the I course did not consider safety as a valuable form of their existence in the environment, while for most graduates of the experimental group, security became a personal need and an integral part of their professional activity (the coefficients of mastering the content of basic concepts in the field of life safety varied within 0.68 0.81 , with $\max =1$ ).

Using the methodology of the author of the concept of psychological safety of the educational environment I.A. Bayeva, we conducted a study of the educational environment of the institution of secondary vocational education, which allows us to determine the main factors of attitude (positive, neutral and negative) of students with disabilities towards it in order to indicate changes in the content of the communicative component of such students' readiness for safe life.

It was found that the majority of students with visual impairment have a positive attitude towards the educational environment (I course - 69.4\%, II course $-73.5 \%$, III course $-86.6 \%$ ), while teachers and students without disabilities - less positive (20.8\% and $29.6 \%$, respectively). This fact served as an occasion to determine the degree of their satisfaction with the educational environment according to several characteristics (relationships with teachers and classmates; emotional comfort; preservation of personal dignity; the ability to seek help, etc.), on a 5-point ranking scale.

Thus, the maximum assessment of the level of satisfaction with the educational environment was noted among students with disabilities of graduation groups, which demonstrated their ability to adapt in the educational organization. They had high satisfaction rates for all characteristics of the educational environment. Satisfaction indicators "opportunity to seek help" were at an average level (3.0), while "relations with classmates and teachers" and "emotional comfort" were at a high level (4.5 and 4.2). To a lesser extent, according to these characteristics, students with a visual impairment of I-II courses were satisfied (2.1; 2.3 and 2.6; 2.4; 2.6 and 3.3 , respectively).

Based on the results obtained, it is worth noting that freshmen with disabilities are slightly less adapted to the educational environment of the educational organization than graduates, which entails some changes in ensuring the safety of their physical and mental health.

In addition to the above, in the training of persons with disabilities, we have identified changes that have occurred in the content of the activity component of the readiness of such students for safe life through tests, 
Busygina T. Alexandrovna, Aleksandr A. Korostelev, Elena I. Artemova, Larisa A. Kolyvanova, Tamara M. Nosova, Ivan I. Pavlov y Svetlana M. Thomas

tests and examinations, which addressed issues of organizing barrierfree professional education; compliance with the rules of safe behavior in everyday and work life, etc.

So, in the course of our study, we determined the indicator of the development of skills by students with impaired health in the field of safe behavior in society, a list of which was developed with the aim of forming their readiness for its implementation. In our opinion, the most significant subject-specific skills in the field of life safety (PU), formed during the training of students with visual impairment, were the ability to correctly assess life-threatening situations and determine safe behavior in them; identify ways to protect against hazards in the field of professional activity; provide first aid to those in need, etc. Figure 1 shows the values of the coefficients of completeness of the acquisition of skills in life safety by persons with disabilities in the process of their professional training.

\section{Conclusion}

So, the data obtained during the study indicate a steady increase in the level of development by students with disabilities of health with professional skills in the learning process (0.638 - 0.822), which indicates their readiness for safe life.

Thus, our analysis of the problem of pedagogical support for the readiness of people with visual impairment for safe life in inclusive education makes a certain contribution to the solution of the problem we have outlined - the problem of a liberal attitude to the low-mobility category of citizens and people with disabilities, changes in the attitude of people around them, and helps to solve actual scientific tasks - tasks of developing a system of pedagogical support for the readiness of persons with various kinds of physical and mental disorders Safe life in the process of their professional training. In this regard, the number of issues requiring further consideration should include the problem of educating the person of a safe type of behavior in the system of inclusive education for disabled people. 


\section{Bibliographic References}

AKHMETOVA, Demitry Irina. 2014. "Will inclusive education accelerate the overcoming social inclusion?” In: Baltic Humanitarian Journal. No. 1, Vol. 6, pp. 36-38.

BAEVA, Ivan Albina; SHAKHOVA, L.I. 2016. "Formation and support of psychological safety of students in cadet classes" In: Psychological and pedagogical research, Vol. 8, No. 4, pp. 91-101.

BAKLUNOVA, Olga Borisovna. 2017. "The social security system in Russia and in Belgium: a comparative analysis" In: Azimuth of Scientific Research: Pedagogy and Psychology, Vol. 6, No. 1, pp. 18-29.

BECK Viktorovna. 2000. "The cosmopolitan perspective: sociology of the second age of modernity" In: The British Journal of Sociology. Special issue: Sociology Facing the Next Millennium / Ed. by John Urry. Vol. 51. $\mathrm{N}$ 1, pp. 79-105.

BELYAEV, Vlademir Pavel; BELYAEV, G.S; CHAPCHIKOV, S. Yu. 2016. "The evolution of the concept of national security" (historical and legal section) part one. In: Legal Concept, No. 3, Vol. 32, pp 12-19.

BOYAROV, Evgenevna Natalia. 2015. "The essence and content of safe information and environmental activities of the Bachelor of Education in the field of life safety" In: Bulletin of Eurasian Science, Vol .7, No.5, pp. 30-56.

CHAIKOVSKYI, Mishel Yagfarovna. 2014. "Inclusion as a condition for free personality development” In: Azimuth of Scientific Research: Pedagogy and Psychology. No. 1, Vol. 6, pp. 77-81.

DANCHENKO, Sarbinaz Pavel. 2016. "Modern problems of learning the basics of life safety” In: Pedagogy of Higher Education, No. 3-1, pp. 68-72.

ELIPKHANOV, Mikhail; OKAZOVA, Z. 2018. "Peculiarities of teaching life safety in the high school" In: Baltic Humanitarian Journal. Vol. 7. No. 3 , Vol. 24, pp. 331-333.

KAMERILOVA, Gabdullaevich Sergei; MEDNIKOVA, O.N; VLASOVA, O.A; KOSTENKO, G.A. 2017. "Electronic presentations in the system of information, communication and learning technologies of life safety" In: Azimuth of Scientific Research: Pedagogy and Psychology. Vol. 6. No. 4, Vol. 21, pp. 81-84. 
Busygina T. Alexandrovna, Aleksandr A. Korostelev, Elena I. Artemova, Larisa A. Kolyvanova, Tamara M. Nosova, Ivan I. Pavlov y Svetlana M. Thomas

KUZNETSOV, Valerievna Nikita. (2009). Sociology of security. Book House University, Moscow, Russia. Pp 20-29.

MEKHANT'YEVA, Lyudmila Elena; SKLYAROVA, T.P; SAPRONOV, G.I; PETROVA, A.V. 2016. "Innovative methods in students training at the department of disaster medicine and life safety" In: Azimuth of Scientific Research: Pedagogy and Psychology. Vol. 5. No. 3, Vol. 16, pp. 89-92.

MINIYAROV, Vladimirovna Mikaiel; ORLOVA, M.A. 2016. "Pedagogical conditions forming of professional competence in safety of activity of the agroengineer" In: T. 5. No. 4, Vol.17, pp. 264-267.

MITIN, Evgenevna Albina; FILIPPOVA, S.O; STANKEVICH, P.V. 2014. "The safety of the physical education environment of the university" In: Scientific notes of the University. PF Lesgaft, No.12, pp. 118-130.

ON NATIONAL SECURITY. 1996. "Message from the President of the Russian" In: Federation to the Federal Assembly. Available online. In: http: // www.kremlin.ru/acts/bank/36349. Date of consultation: 04/11/2018.

PONEDELKOV, Alla Vladimirovna. (2015). On the Perception of National Security Issues at Regional Level. Vestnik Volgogradskogo Gosudarstvennogo Universiteta. Seriia 4, Istoriia,- Regionovedenie, Mezhdunarodnye Otnosheniia,20(6).

RYBALKIN, Natalia Nadezda. 2006. Safety philosophy. Publishing House Mosk. psycho-social in-that. Moscow, Russia.

SAMYGIN, Sarbinaz Ivanova; VERESHCHAGIN, A.V. (2014a). "Global challenges of our time and the security of civilization of the third millennium” In: European Social Science Journal, (6-2), pp. 60-66.

SHAKHOVA, Lyudmila Ivanova. 2015. "Study of the psychological safety structure of elementary schoolchildren and cadet students" In: Bulletin of the Russian State Pedagogical University. AI Herzen, (178), pp. 24-30.

SHUVALOVA, Vladimirovna Olga. 2018. "Level and standard of living: factors and Russian specificity" In: Azimuth of Scientific Research: Economics and Administration. T. 7. No. 1 (22), pp. 276-279.

SOLOMIN, Valerievna Pavel; STANKEVICH, P.V. 2014. "Genesis of the development of level pedagogical education in the field of life safety" In: Young Scientist, (18-19), pp. 4-6.

TSVETKOVA, Irina Valentina. 2018. "Approaches to teaching pupils and student's life safety” In: Karelian Scientific Journal. Vol. 7. No. 2 (23), pp 48-52. 
YAKOVLEVA, E.L. 2014. "The reasons distribution inclusion and inclusive education (philosophical aspect of the problem)" In: Karelian Scientific Journal. No. 4 (9). pp. 26-29.

YAKUPOV, Alexandra Mariana. 2008. "The concepts of "danger" and "safety" as philosophical categories" In: Actual problems of the formation of a culture of life safety, pp. 70-82). 


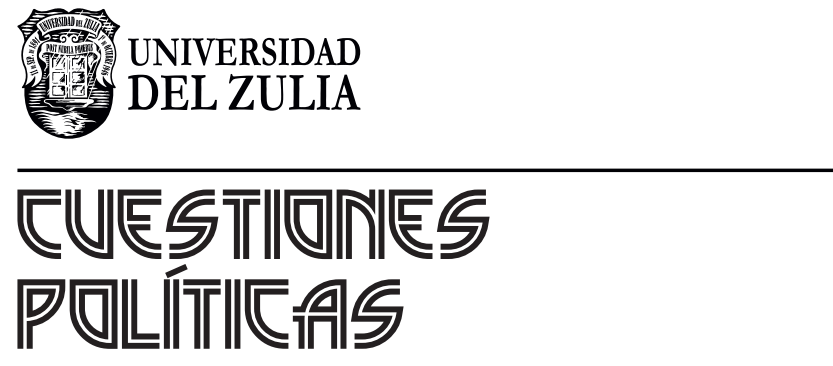

Vol. $37 \mathrm{~N}^{\circ} 64$

Esta revista fue editada en formato digital y publicada en mayo de 2020, por el Fondo Editorial Serbiluz, Universidad del Zulia. Maracaibo-Venezuela 